\title{
Book Recommendation
}

Kenneth E. Bauzon's Capitalism, The American Empire, and Neoliberal Globalization:

Themes and Annotations from

Selected Works of E. San Juan, Jr.

\section{Jeffrey Arellano Cabusao}

\section{Bryant University, Rhode Island}

\section{Abstract}

This critical book review highlights the significance of Kenneth E. Bauzon's Capitalism, The American Empire, and Neoliberal Globalization: Themes and Annotations from Selected Works of E. San Juan, Jr. (2019) for Filipinos in the Philippines, the United States, and throughout the diaspora. Bauzon's text (its form and content) builds upon a unique genre of Filipino alter/native writing while it simultaneously inventories the intellectual contributions of prolific scholar and public intellectual E. San Juan, Jr. whose work has bridged Philippine studies, Filipino American studies, ethnic studies, literary studies, and cultural studies for nearly six decades. In order to confront the trauma of history and, at the same time, to move forward collectively, Filipinos must reimagine traditions of anticolonial resistance (part of the process of becoming Filipino). Through its dialogic relationship with San Juan's body of work (positioned as a repository of collective memory of Filipino resistance), Bauzon's text makes a compelling case for the continued relevance of the movement for Filipino sovereignty in the 21st century-a tradition of struggle that speaks specifically to the emancipation of Filipinos everywhere as it is interconnected with the liberation of all oppressed and marginalized peoples in the era of neoliberal globalization. 


\section{Keywords}

US Colonialism, US Racism, Philippine-American War, Filipino Writing, Filipino Resistance, E. San Juan, Jr. 
As an act of solidarity with the 2020 global uprising to protest the killing of African American George Floyd at the hands of Minnesota police officers (a manifestation of a long history of anti-Black racist violence in the United States), Filipino American James Juanillo decided to furnish the outside of his home in San Francisco with signs in support of the daily protests. As he was completing a chalking of the phrase "Black Lives Matter" on the retaining wall of his home, Juanillo was accosted by a white couple (Lisa Alexander and Robert Larkins) accusing him of a crime-defacing private property which, the couple claimed, did not belong to him. According to Juanillo, his home is located in "Pacific Heights, an affluent, predominantly white San Francisco enclave... [a neighborhood where] brown people aren't supposed to be... unless they're the nannies or the plumbers." ${ }^{1}$ This particular episode reveals, on the one hand, the interconnectedness between anti-Filipino and antiBlack racisms; on the other, it highlights just how destabilizing and threatening interethnic solidarity can be in a society that is historically structured around white supremacy. Juanillo's act of interethnic solidarity with African Americans was so threatening that Lisa Alexander decided to call the police.

Juanillo's expression of solidarity with African Americans in the face of white racist hostility taps into a long memory-a history of Filipino/African American solidarity that developed at the beginning of the $20^{\text {th }}$ century in the Philippines. Kenneth E. Bauzon's Capitalism, The American Empire, and Neoliberal Globalization: Themes and Annotations from Selected Works of E. San Juan, Jr. (2019) returns us to a time when Filipino revolutionaries, mobilizing against US colonial occupation of the Philippines, forged solidarity with African American Buffalo soldiers such as David Fagen who defected and joined the anticolonial Filipino movement. Interethnic solidarity is one of many themes of the Filipino experience that Bauzon examines in his new work.

In Capitalism, Bauzon traces the unfolding of US empire-specifically the ways in which "manifest destiny... was asserted over the Pacific" to justify US colonization of the Philippines (1899-1946). ${ }^{2}$ By using an interdisciplinary approach that centers the Filipino historical experience, Bauzon provides an alternative narrative of US empire-one that not only examines how 
Filipinos have been victimized by colonialism but also how Filipinos have collectively responded and resisted as agents of history. The text examines the rise of the American empire in the Pacific (from the Malolo Massacre in 1840 to the Philippine-American War of 1899-1913) and the subsequent neocolonial period in the Philippines (from the Cold War period to the era of neoliberal globalization). ${ }^{3}$

A meditation on the historical linkages between the three keywords that comprise the main title, Bauzon's text enables readers to examine the interconnectedness between the historical development of capitalism (its rise "as a system of accumulation of value"), the establishment of an American empire (at the turn of the $20^{\text {th }}$ century in the Philippines), and the rise of neoliberal globalization ("a reincarnation of classical colonialism") with an emphasis on challenging the historical limitations of academic forms of knowledge (from postcolonialism to multiculturalism) that obscure the brutality of each aforementioned stage of global capitalism. ${ }^{4}$ An erudite scholar deeply rooted in a progressive Filipino intellectual tradition, Bauzon simultaneously honors the contributions of preeminent and prolific Filipino literary scholar, cultural theorist, and public intellectual E. San Juan, Jr. (one "deserving of recognition as Philippine national treasure") who functions as his interlocutor throughout the study. ${ }^{5}$

Bauzon provides a much-needed intervention in his retrieval of that which has been silenced, suppressed, and dismissed in the study of global capitalism. By utilizing a historical materialist perspective, Bauzon challenges the ways in which various academic disciplines (from sociology and political science to literature) have retreated from the concept of class. In addition, Bauzon centers US-Philippines colonial relations-a topic that is "usually... ignored or papered over by mainstream historians." ${ }^{\circ}$ On the one hand, Bauzon's text meticulously traces how US colonization of the Philippines played a key role in the rise and establishment of American empire and continues to inform our contemporary moment of neoliberal globalization; on the other, it reveals the complexity of class struggle by highlighting the struggle for Filipino self-determination-a movement that 
has endured despite its violent suppression by US colonial forces in the early $20^{\text {th }}$ century.

A distinguishing key feature of Bauzon's text is its form. Throughout Capitalism, annotations from E. San Juan, Jr.'s massive body of writings are utilized to illuminate various dimensions of the history of global capitalism from both a historical materialist perspective and an anticolonial Filipino perspective. This particular approach generates a dialogic relationship between two generations of Filipino intellectuals (Bauzon and San Juan) and between Capitalism and a unique genre of Filipino writing ("over a century old") that is inextricably intertwined with the process of Filipino becoming-a collective desire for national sovereignty. Bauzon explains that the form of Capitalism is inspired by Dr. Jose Rizal's approach to reading and re-envisioning Filipino history:

In 1888, Dr. Jose Rizal, who would be the Philippines' foremost hero, began his search at the British Museum for... Sucesos De Las Islas Filipinas (Historical Events of the Philippine Islands) written by ... Dr. Antonio Morga [published in 1609]. Rizal's interest was in learning how Morga, an influential lay historian and colonial bureaucrat ... . narrated the history of Spanish colonial administration of the Philippine Islands .... Based on his own research and accumulated knowledge, Rizal ... went about the laborious process of annotating the book which, upon completion, he published in Paris in $1889 .$. . Rizal deemed his annotations essential to correcting Morga's views about the Filipinos, their pre-conquest civilization up until 1532, the nature of Spanish colonial policies and practices, and how these had contributed to the social and economic backwardness of the Filipinos. Without perhaps intending it, Rizal had, in fact, through his annotations, written the country's first systematic history from the Philippine viewpoint. ${ }^{7}$

Just as Rizal's annotations provided a corrective to Morga's orientalist discourse of European "superiority”/Filipino “otherness”, San Juan's annotations in Capitalism provide a corrective to mainstream scholarship on global capitalism that has erased class and silenced Filipino subaltern voices of resistance. According to Bauzon, San Juan's interventions within his text "offer an alternative meaning of history that would otherwise be different without such interventions." 
Bauzon's Capitalism is a significant contribution to a genre of Filipino writing that centers (to borrow a term from San Juan) "alter/native" Filipino voices that (in the words Amilcar Cabral) "return to the source"-voices connected to the collective subaltern struggle for Filipino national sovereignty. By juxtaposing the form of Capitalism with Rizal's re-envisioning of Sucesos De Las Islas Filipinas in the late $19^{\text {th }}$ century, Bauzon has created a text that builds upon (and is in dialogue with) a rich tradition of alter/native Filipino writing which includes works by Delia D. Aguilar, Carlos Bulosan, Renato Constantino, Dolores S. Feria, Amado V. Hernandez, Ninotchka Rosca, E. San Juan, Jr., Jose Maria Sison, among others.

Bauzon, who is formally trained as a political scientist, has produced a text that is interdisciplinary and global in scope. In his examination of the complexity of global capitalism, US empire, and Filipino subaltern revolt, Bauzon engages a wide variety of academic fields and methodologiesphilosophy, political science, cultural studies, sociology, history, historical materialism, and discourse analysis. Capitalism is comprised of eight chapters that address the historical unfolding of global capitalism with particular emphasis on the history of US empire, the US as racial polity, and emancipatory movements for social justice. Three chapters focus on the US colonization of the Philippines with detailed attention to US atrocities committed in "Mindanao and [the] Sulu region, traditional home of Muslim Filipinos." Bauzon's careful examination of the brutality of the Philippine-American War (1899-1913-considered the "first Vietnam") is a sobering reminder of the following key ideas on the intersection of US empire, knowledge production, and violence:

1.) The painful history of the American civilizing (read: genocidal) mission in the Philippines has been silenced, obscured, or distorted (if made visible) within various academic fields of study-from history to postcolonial studies.

2.) US colonial suppression of the anticolonial Filipino revolution for national sovereignty paved the way for future counterinsurgency programs within and without the United States, endless US wars through the $20^{\text {th }}$ and 
into the $21^{\text {st }}$ centuries, and the reincarnation of colonialism in the age of neoliberal globalization.

3.) Barbarism, as political scientist Onur Ulas Ince argues, "constituted a dynamic internal to the historical emergence of global capitalist relations within the politico-legal framework of colonial empires." ${ }^{\prime 10}$

Bauzon writes thoughtfully and boldly against historical amnesia by detailing and making visible the horrors of the Philippine-American Warover one million Filipinos and over 4,200 American soldiers lost their lives. ${ }^{11}$ Historical amnesia with regard to US colonial genocide in the Philippines is not limited to the world of the academy. When American filmmaker and novelist John Sayles conducted research for his film on the PhilippineAmerican War titled Amigo (2010), he was astounded to discover that his film would become "the third movie ever made in the United States about the Philippine-American War." In an interview, Sayles expresses his deep concern with the profound silence and erasure of a significant historical chapter of the United States and the Philippines:

How come there are no novels about it [the Philippine-American War]? How come it's not in our history books [in the United States]? And then asking my Philippine and Philippine-American friends what they knew about it, they said, "Well, we kind of know about it, but it was not taught in our schools." How is something that-that's like not teaching the American Revolution in American schools. You know, how does a piece of history, where probably a million Filipinos died, get plowed under like that? And why? ${ }^{12}$

Not unlike Toni Morrison's notion of rememory (the past existing in the present), the historical trauma of US colonial annihilation of Filipino national sovereignty continues to haunt nearly 12 million Overseas Filipino Workers (OFWs) scattered across the planet and over 100 million Filipinos in the Philippines, an island nation that continues to exist as a US neocolony. 


\section{Alter/native Return: On Race, Class, and National Liberation}

Bauzon's Capitalism contributes to the current revival of the Marxist critical tradition which includes recent publications such as Barbara Foley's Marxist Literary Criticism Today (2019) and Richard Wolff's Understanding Marxism (2019). Emerging within a critical, historical moment that demands critique and sustained mass action against the ruling class of global capitalism, Capitalism also contributes to a broad intellectual tradition that has courageously resisted the neoliberal cultural turn (post-ality) within the US academy which came to fruition precisely when mass movements of the New Left period were being dismantled. ${ }^{13}$ This intellectual tradition includes writers such as Aijaz Ahmad, Ama Ata Aidoo, Tithi Bhattacharya, Michel Beaud, Vivek Chibber, Noam Chomsky, Angela Davis, Peter Drucker, Teresa Ebert, Nawal El Saadawi, Marcial Gonzalez, Donald Morton, Cornel West, Ellen Meiksins Wood, Mas'ud Zavarzadeh, Howard Zinn to name a few. For these writers, class is an indispensable category. In their own ways, they have resisted the retreat from class evident within various spaces of the academy (from the work of Hardt and Negri to the field of postcolonial studies) and within the domain of public intellectual work (see Cornel West's critique of the limitations of Ta-Nehisi Coates). ${ }^{14}$

By returning to class, Capitalism contributes to reviving a Filipino Marxist intellectual tradition. Bauzon's text joins recent publications within this tradition such as Writer in Exile/Writer in Revolt: Critical Perspectives on Carlos Bulosan (2016); E. San Juan, Jr.'s Carlos Bulosan: Revolutionary Filipino Writer in the United States (2017); Penguin Classics edition of Carlos Bulosan's America Is in the Heart (2019). In light of the pioneering work of Filipino author Carlos Bulosan (from the era of the Great Depression to the start of the Cold War period) and the prolific output of E. San Juan, Jr., we are able to discern how Filipino Marxism functions as the theoretical spine of the genre of alter/native Filipino writing-a genre of writing interconnected with the process of Filipino becoming.

Bauzon's Capitalism serves as companion text to the 2008 San Juan anthology From Globalization to National Liberation: Essays of Three Decades (University of the Philippines Press). By providing a magnificently detailed 
and insightful inventory of key concepts from San Juan's large body of work (within its body and copious endnotes), Bauzon envisions new possibilities within the field of Filipino Marxist thought. Bauzon's text also functions as a companion to recently published works that have renewed interest in Carlos Bulosan for whom Filipino Marxism was central and vital to exercising, nurturing, and developing a diasporic literary imagination. In his essay, “The Writer as Worker” (excerpted from a 1955 letter), Bulosan states the following:

Filipino writers in the Philippines have a great task ahead of them, but also a great future. The field is wide and open. They should rewrite everything written about the Philippines and the Filipino people from the materialist, dialectical point of view-this being the only [way] to understand and interpret everything Philippines. They should write lovingly about its rivers, towns, plains, mountains, wildernesses-its flora and fauna-the different tribes and provinces. They should write about the great men and their times and works, from Lapulapu to Mariano Balgos. They should compile the unwritten tales, legends, folklore, riddles, humor, songs, sayings. They should illustrate that there was a culture before the Spaniards uprooted it. When these are written, they should extenuate and amplify. The material is inexhaustible. But always they should be written for the people, because the people are the creators and appreciators of culture. . . ${ }^{15}$

As a Filipino writer in the United States, Bulosan took a resolute stand with the working classes in the United States, the Philippines, and around the globe. His writings (novels, short stories, poems, essays, letters) document the development of Filipino Marxist thought in the $20^{\text {th }}$ century. To be sure, Bulosan's central characters (Allos in America Is in the Heart, Dante in The Cry and the Dedication for example) embody the heart of Filipino Marxisman affirmation of peasant/worker subjectivity and agency within Philippine colonial/neocolonial society and the Filipino Diaspora.

Since the institutionalization of postcolonial studies within the Western academy, Filipino academics over the past few decades have had to move through the postcolonial field in order to examine the Filipino experience in the United States, the Philippines, and the diaspora-by either simply applying its theoretical concepts (from hybridity/mimicry/interstices to 
more recent concepts such as the postnational) or by actually interrogating the theoretical assumptions that undergird the postcolonial enterprise. ${ }^{16} \mathrm{By}$ far, E. San Juan, Jr. has provided the most durable and sustained critique (for over two decades) of the historical limitations of the field of postcolonial studies-especially in relation to the Filipino experience. For instance, in Racism and Cultural Studies (2002), San Juan (leaning upon Mary Louise Pratt) takes postcolonial studies to task for its inability to critique the phenomenon of neocolonialism. ${ }^{17}$ Bauzon's Capitalism (in chapters 7 and 8) advances San Juan's critique of postcoloniality by opening a space for us to imagine new possibilities for a Filipino Marxist tradition in the $21^{\text {st }}$ century (connecting knowledge production with social transformation).

Capitalism illustrates how Filipino Marxism functions as a corrective to postcolonial blind spots, especially with regard to US-Philippines colonial and neocolonial relations. On the one hand, Filipino Marxism recognizes that the Filipino subaltern has always spoken-it affirms the collective agency of the colonial/neocolonial subaltern subject; ${ }^{18}$ on the other hand, Filipino Marxism recognizes (not unlike the field of postcolonial studies) the severe historical limits and contradictions of the European Enlightenment-its racist ideologies and history of colonial plunder and genocide. The appeal of Filipino Marxism today, particularly to the global 99\%, is its rearticulation of what remains useful from modernity-ideals such as universal human rights (metanarrative of emancipation). San Juan identifies a peculiar aporia within postcolonial studies stemming from its particular reading of the history of capitalism in the following:

The conflation of Enlightenment ideals with the telos of utilitarian capitalism and its encapsulation in the historiographic fortunes of modernity have led to a nominalist conception of subjectivity and agency. Disavowing modernity and the principle of collective human agency-humans make their own history under determinate historical conditions-postcolonialism submits to the neoliberal cosmos of fragmentation, individualist warfare, schizoid monads, and a regime of indeterminacy and contingency. The ironic turn damages postcolonialism's claim to liberate humanity from determinisms and essentialisms of all kinds. ${ }^{19}$ 
Blending historical materialist and Filipino alter/native approaches (to generate a Filipino Marxist perspective), Capitalism advances San Juan's rigorous critique by focusing on that which the field of postcolonial studies has been unable to critique-the rise/development and global hegemonic position of the imperial US state.

Through its Filipino Marxist optic, Capitalism provides a framework for understanding the specificity of Filipino oppression-one that occurs in the forms of racial and national subordination. Bauzon's chapters on US-Philippines relations and US racism (specifically 3, 4, 5, and 7) build upon the work of Charles Mills which, according to San Juan, enables us to conceptualize the United States as a racial polity-a nation "founded on the genocidal confinement of the indigenous Indians, the slavery and segregation of blacks, the conquest of Spanish-speaking natives, and the proscription of Asian labor." ${ }^{20}$ It is within this historical context of white-supremacist nation building that the United States colonized the Philippines. As a result, Filipinos have a distinct relationship to the United States. San Juan and Bruce Occena remind us of two historical conditions that distinguish Filipinos from other Asian groups in the United States in the following:

... . first, the continuing oppression of the Filipino nation by U.S. imperialism; and second, the fact that as a group "Filipinos have been integrated into U.S. society on the basis of inequality [US-Philippines colonial/neocolonial relations] and subjected to discrimination due both to their race and nationality." 21

The racial-national subordination of Filipinos is dramatized by an American Pacific Orientalist discourse which Bauzon examines by way of Nerissa Balce's recent work. Balce helps us to see how orientalist representations of Filipinos in the early $20^{\text {th }}$ century (for example the photographs of zoologist Dean Worcester) were used in the service of US "military surveillance, war, and the maintenance of... military rule in the lands."22 Bauzon's and Balce's insights are a fine complement to The Forbidden Book: The PhilippineAmerican War in Political Cartoons (2004), a powerful repository of American Pacific orientalist imagery in political cartoons produced at the inception of 
the American empire. The Forbidden Book continues to be an incredibly rich resource for classroom instruction on US-Philippines relations.

\section{Solidarity and Fillipino Becoming}

Capitalism's alter/native approach to Filipino writing provides tools for confronting the wounds of history. It reminds readers that the genuine national liberation of the Philippines is key to the emancipation of Filipinos everywhere. It also sheds light on how the process of Filipino becoming could play a key role in global struggles for social justice. When I was in college, I was fortunate to have Ghanaian writer Ama Ata Aidoo as my professor throughout my first year at Oberlin. During one of my many visits to her office hours, she told me of how she and others throughout Africa were watching and cheering the Filipino people as they mobilized to topple the Marcos dictatorship in 1986. She then looked at me and said that I have every right to be proud to be Filipino. I left Aidoo's office with an incredible sense of joy at the thought of the resourcefulness and militancy of the Filipino people. I was also very proud of the way in which the anticolonial movement for Filipino self-determination inspired others around the globe. As Bauzon highlights, interethnic and interracial solidarity has been a longstanding key component of Filipino becoming-from the African American Buffalo soldiers (such as David Fagen) in the Philippines to W.E.B. Du Bois ... from Paul Robeson to Ama Ata Aidoo.

In his concluding chapter, Bauzon provides an opportunity for us to consider the ways in which Filipino becoming could contribute to and enhance contemporary social movements-from activism in the United States (\#BlackLivesMatter, immigrants' rights, \#StopAsianHate) to the global environmental justice movement. In many ways, Capitalism is in dialogue with recent materials on social justice-Noam Chomsky's Requiem for the American Dream, Naomi Klein's This Changes Everything, Keeanga-Yamahtta Taylor's From \#BlackLivesMatter to Black Liberation, Greta Thunberg's (I Know This To Be True): On Truth, Courage \& Saving Our Planet, and Jose Antonio Vargas's Dear America: Notes of an Undocumented Citizen. 
Here I return to James Juanillo's story in San Francisco-one that reveals the interconnectedness of anti-Filipino and anti-Black racisms in the United States. Juanillo's story of interethnic Filipino/African American solidarity has the potential to enhance the global dimension of solidarity embedded with the process of Filipino becoming. While Trump pushed to militarize the police force in the United States in response to anti-racist protests against police brutality (a call for "law and order"), the US State Department approved a two billion dollar arms deal with Duterte-a deal that promises to intensify human rights violations in the Philippines by militarizing the war on drugs and policies to silence political dissent. ${ }^{23}$ The intersection of militarized repression of political dissent in the United States and the Philippines requires a collective, global response rooted in solidarity.

As African American activist and philosopher Angela Davis noted recently, the mass uprisings around the globe against the killing of George Floyd provide a direct critique of the neoliberal ideology of individualism. ${ }^{24}$ The vibrant multiracial uprisings (in the midst of the COVID-19 pandemic, environmental degradation, and a global migrant crisis) call for a systemic critique of global capitalism. We are fortunate to have Bauzon's new book at this historical moment. Capitalism is a text that reminds us of the potential of Filipino becoming-it is the key to Filipino self-determination as well as a vehicle for envisioning new forms of global solidarity essential to creating a more humane and just future for all. 


\section{Notes}

1. "Filipino American confronted for BLM message sheds light on form of genteel racism, experts say." www.nbcnews.com/news/asian-america/filipino-american-confronted-blm-message-sheds-light-form-genteel-racism-n1231409.

2. Bauzon, p. viii.

3. For more on the Malolo Massacre, see Bauzon, pp. 33-53.

4. Here I lean upon Raymond Williams's notion of keywords-his emphasis on the shifting social, historical, and cultural meanings and ideological function of a word. See Raymond Williams's Keywords, Bauzon, p. 18.

5. See "San Juan, Jr./Curriculum Vitae”, Kritika Kultura, 2016.

6. Bauzon, p. 18.

7. Bauzon, p. xiii.

8. Bauzon, p. xiii.

9. Bauzon, p. 116.

10. Ince 2018 quoted by Bauzon, p. 8 .

11. The Forbidden Book, p. 97.

12. "A Moment in the Sun": An Extended Interview with Independent Filmmaker, Author John Sayles." Democracy Now! www.democracynow. org/2011/7/4/a_moment_in_the_sun_an.

13. See Vivek Chibber's "On the Decline of Class Analysis in South Asian Studies."

14. For Bauzon's discussion of Hardt and Negri, see pp. 11-14; for West's critique of Coates, pp. 207-210.

15. Bulosan, On Becoming Filipino, p. 144.

16. See Vivek Chibber's Postcolonial Theory and the Specter of Capital.

17. San Juan, Racism and Cultural Studies, p. 278.

18. See San Juan's Beyond Postcolonial Theory and Ebert's "Women and/as the Subaltern" in Ludic Feminism, pp. 283-302.

19. San Juan, Racism and Cultural Studies, p. 267.

20. San Juan, Toward Filipino Self-Determination, p. 43. See also Charles W. Mills, The Racial Contract.

21. San Juan, "In Search of Filipino Writing", Asian American Studies Reader, pp. 450-451.

22. From Nerissa Balce's Body Parts of Empire: Abjection, Filipino Images and the American Archive quoted by Bauzon, p. 158.

23. Amee Chew, "Stop the $\$ 2$ Billion Arms Sale to the Philippines", Jacobin, May 17, 2020; "ICHRP-US Demands Accountability for Approved 2 Billion Dollar Arms Sale to Duterte", International Coalition for Human Rights in the Philippines, May $1,2020$. 
24. "Uprising \& Abolition: Angela Davis on Movement Building, "Defund the Police” \& Where We Go from Here.” www.democracynow.org/2020/6/12/ angela_davis_historic_moment; see also Davis's Freedom Is a Constant Struggle: Ferguson, Palestine, and the Foundations of a Movement. 


\section{Works Cited}

Bauzon, Kenneth E. Capitalism, The American Empire, and Neoliberal Globalization:

Themes and Annotations from Selected Works of E. San Juan, Jr. Palgrave

Macmillan; De La Salle University, 2019.

Bulosan, Carlos. America Is in the Heart. Penguin, 2019.

---. The Cry and the Dedication. Temple UP, 1995.

---. On Becoming Filipino, edited by E. San Juan, Jr., Temple UP, 1995.

Cabusao, Jeffrey Arellano, editor. Writer in Exile/Writer in Revolt: Critical

Perspectives on Carlos Bulosan. UP of America, 2016.

Chew, Amee. "Stop the \$2 Billion Arms Sale to the Philippines." Jacobin, May 17, 2020, jacobinmag.com/2020/05/arms-sale-philippines-rodrigo-duterte.

Chibber, Vivek. "On the Decline of Class Analysis in South Asian Studies." Critical Asian Studies, vol. 38, no. 4, 2006, pp. 357-387.

---. Postcolonial Theory and the Specter of Capital. Verso, 2013.

Davis, Angela Y. Freedom Is a Constant Struggle: Ferguson, Palestine, and the Foundations of a Movement. Haymarket Books, 2016.

Ebert, Teresa L. Ludic Feminism and After: Postmodernism, Desire, and Labor in Late Capitalism. U of Michigan P, 1996.

Foley, Barbara. Marxist Literary Criticism Today. Pluto Press, 2019.

Goodman, Amy. “'A Moment in the Sun': An Extended Interview with Independent Filmmaker, Author John Sayles.” Democracy Now! July 4, 2011, www.democracynow.org/2011/7/4/a_moment_in_the_sun_an.

---. "Uprising \& Abolition: Angela Davis on Movement Building, 'Defund the Police’ \& Where We Go from Here.” Democracy Now! June 12, 2020, www. democracynow.org/2020/6/12/angela_davis_historic_moment.

Hutchison, Peter, et al., directors. Requiem for the American Dream. PF Pictures in association with Naked City Films, 2016.

"ICHRP-US Demands Accountability for Approved 2 Billion Dollar Arms Sale to Duterte."

International Coalition for Human Rights in the Philippines, May 1, 2020, ichrpus. org/2020/05/01/ichrp-us-demands-accountability-for-approved-2-billiondollar-arms-sale-to-duterte/.

Ignacio, Abe, et al., editors. The Forbidden Book: The Philippine-American War in Political Cartoons. T’Boli Publishing and Distribution, 2004.

Klein, Naomi. This Changes Everything: Capitalism vs. the Climate. Simon \& Schuster, 2014.

Mills, Charles W. The Racial Contract. Ithaca: Cornell UP, 1997.

“San Juan, Jr./Curriculum Vitae." Kritika Kultura, vol. 26, 2016, pp. 482-522, kritikakultura.ateneo.net. 
San Juan, Jr., E. Beyond Postcolonial Theory. St. Martin's Press, 1998.

---. Carlos Bulosan: Revolutionary Filipino Writer in the United States. Peter Lang, 2017.

---. From Globalization to National Liberation: Essays of Three Decades. U of the Philippines P, 2008.

---. Racism and Cultural Studies: Critiques of Multiculturalist Ideology and the Politics of Difference. Duke UP, 2002.

---. "In Search of Filipino Writing: Reclaiming Whose 'America'?" Asian American Studies Reader, edited by Jean Yu-wen Shen Wu and Min Song, Rutgers UP, 2000.

---. Toward Filipino Self-Determination: Beyond Transnational Globalization. State U of New York P, 2009.

Taylor, Keeanga-Yamahtta. From \#BlackLivesMatter to Black Liberation. Haymarket Books, 2016.

Thunberg, Greta. (I Know This To Be True): On Truth, Courage \& Saving Our Planet. Murdoch Books, 2020.

Vargas, Jose Antonio. Dear America: Notes of an Undocumented Citizen. HarperCollins Publishers, 2018.

Wang, Claire. "Filipino American confronted for BLM message sheds light on form of genteel racism, experts say." NBC News, June 18, 2020, www.

nbcnews.com/news/asian-america/filipino-american-confronted-blm-message-sheds-light-form-genteel-racism-n1231409.

Williams, Raymond. Keywords: A Vocabulary of Culture and Society. Oxford UP, 1976.

Wolff, Richard. Understanding Marxism. Democracy at Work, 2019. 